\title{
COMMENTS
}

\section{The Corporate Opportunity Doctrine and Outside Business Interests}

\author{
Michael Begert $\dagger$
}

When a patient approaches a doctor in a medical corporation, the doctor may not treat the patient outside of the corporate clinic and keep the proceeds for herself. Such conduct is forbidden by the corporate opportunity doctrine: that body of law that prohibits corporate fiduciaries from diverting business opportunities from their corporations to themselves. By contrast, the corporation surely cannot complain if the doctor maintains a portfolio of publicly traded securities for her own profit. Such trading would not amount to a breach of the fiduciary's duties under the corporate opportunity doctrine. Between these two extremes lie countless instances in which actions of corporate participants fall on the uncertain line separating acceptable personal business undertakings from disloyalty to the corporation.

This uncertainty has produced a confusion of approaches to corporate opportunity in the state courts. ${ }^{1}$ To remedy this situation, the American Law Institute ("ALI") has included a reformulation of the corporate opportunity doctrine in its corporate governance project. $^{2}$ The ALI rule, as tentatively drafted, would require that corporate participants fully disclose and obtain a for-

$\dagger$ B.A., University of Washington, 1985, J.D. Candidate, 1989, The University of Chicago.

1 Victor Brudney and Robert Charles Clark, A New Look at Corporate Opportunities, 94 Harv L Rev 997, 998 (1981).

${ }^{2}$ American Law Institute, Principles of Corporate Governance: Analysis and Recommendations $§ \S 5.05,5.12$ at 104, 184 (Tentative Draft No 5) (ALI, 1986) ("ALI Project"). To date, two states have adopted the ALI's reformulation of the corporate opportunity doctrine: The Oregon Supreme Court in Klinicki v Lundgren, 298 Or 662, 695 P2d 906, 917-18 (1985), and the Tennessee Court of Appeals in Tennessee Bearing and Supply, Inc. v Parrish, 1988 WL 122337 (Tenn App). 
mal rejection of outside business opportunities before taking advantage of such opportunities as individuals.

This comment argues for a doctrine of corporate opportunity that is more organized than under the common law, but more lenient than under the ALI reformulation. Section I of the comment sets out the various factors that courts use in enforcing the doctrine, and critiques the common law tests that attempt to synthesize these factors. Section II explains the ALI's proposal and argues that it intrudes unreasonably into the individual's ability to conduct outside business. Section III proposes a more lenient rule that protects a corporation's own interests without destroying individual incentives to seek out lucrative investments.

\section{Analysis of the Common Law}

When may a corporation hold a corporate participant liable for engaging in a business transaction that would have benefited the corporation? The answer, under the common law, has varied widely with the factual circumstances of each case. ${ }^{3}$ Thus, courts, attorneys, and corporate participants are faced with decisions based on a myriad of highly particular fact patterns. Attempts to organize these decisions into a coherent set of rules are frustrated by subtle distinctions between precedents. The rules that can be discerned are riddled with exceptions, thereby providing precious little guidance to corporate participants. ${ }^{4}$

The leading case on corporate opportunity is Guth $v$ Loft, Inc. ${ }^{5}$ Guth, the dominant director of Loft, a soda fountain chain, set out to find a substitute for Coca Cola to use in the corporation's stores. He settled on the Pepsi Cola formula, which he purchased for himself. ${ }^{\cdot}$ Using corporate money and personnel, he then developed the Pepsi Company. In response to a lawsuit brought by the corporation, the Delaware Court ordered Guth to give the Pepsi Company to the Loft Corporation.

The court in Guth explained that the restriction on the ability

3 "The occasions for the determination of honesty, good faith and loyal conduct are many and varied, and no hard and fast rule can be formulated." Guth v Loft, Inc., 23 Del Chanc 255, 5 A2d 503, 510 (Sup Ct 1939).

"Although courts often refer to "tests" or "rules," the common law corporate opportunity doctrine more closely resembles a long list of factors, and "[t]he presence or absence of any single factor is not determinative of the issue of corporate opportunity." Paulman $v$ Kritzer, 74 Ill App 2d 284, 219 NE2d 541, 546 (2d D 1966), aff'd 38 Ill 2d 101, 230 NE2d 262 (1967).

- 23 Del Chanc 255, 5 A2d 503 (Sup Ct 1939).

- The National Pepsi Cola Corporation had recently entered bankruptcy. Id at 505. 
of corporate directors and officers to take opportunities for themselves is one manifestation of the general duty of loyalty owed to the corporation by corporate fiduciaries. ${ }^{7}$ In general, the fiduciary duty that directors and officers owe the corporation is one of utmost good faith and fair dealing. ${ }^{8}$ When defining the fiduciary duty in the corporate opportunity context, the courts in many jurisdictions cite the language of Guth:

[I]f there is presented to a corporate officer or director a business opportunity which the corporation is financially able to undertake, is, from its nature, in the line of the corporation's business and is of practical advantage to it, is one in which the corporation has an interest or a reasonable expectancy, and, by embracing the opportunity, the self-interest of the officer or director will be brought into conflict with that of his corporation, the law will not permit him to seize the opportunity for himself. ${ }^{\ominus}$

As with most duty of loyalty questions, courts have approached questions involving a fiduciary's use of business opportunities with an attitude of suspicion.

\section{A. The Common Law Factors}

At common law, courts developed a host of factors for determining whether a participant's ${ }^{10}$ fiduciary duty requires her to pass up a business opportunity, or whether, instead, she is free to take it for herself. Though the application of these factors has varied

7 Id at 510. See also Gauger v Hintz, 262 Wis 333,55 NW2d 426, 435-436 (1952).

8 Justice Cardozo's language in Meinhard $v$ Salmon remains the classic statement on fiduciary duty: "Many forms of conduct permissible in a workaday world for those acting at arm's length, are forbidden to those bound by fiduciary ties. A trustee [fiduciary] is held to something stricter than the morals of the market place. Not honesty alone, but the punctilio of an honor the most sensitive, is then the standard of behavior. As to this there has developed a tradition that is unbending and inveterate." 249 NY 458, 164 NE 545, 546 (1928).

- 5 A2d at 511 . That a Delaware case has proved to be a standard should not, however, be misinterpreted as an indication that Delaware courts dominate interpretation of the corporate opportunity doctrine in the way they dominate other areas of corporate law. Since most corporate opportunity cases involve small corporations incorporated in their home states, most of the actions are not brought in Delaware courts. Indeed, the lack of organization and clarity in this area may be partly attributed to the lack of guiding influence from a single dominant jurisdiction. For significant corporate opportunity cases outside of Delaware, see, for example, Miller v Miller, 301 Minn 207, 222 NW2d 71 (1974) and Klinicki v Lundgren, 298 Or 662, 695 P2d 906 (1985).

${ }^{10}$ To avoid confusion, this comment will refer to corporate officers, directors, and shareholders as "participants." This terminology conforms to the realities of close corporation life where the same individuals are likely to fill all of those roles. 
from state to state, certain considerations have proved dominant: whether the corporation has a previous connection to the opportunity; whether the opportunity is essential to the corporation; whether the corporation has the ability to undertake the opportunity; and whether the corporation has consented to the transaction.

Although these factors can be extracted from the case law, the corporate participant will find it difficult to use them as a guide to behavior under the current regime, since in any given case a factor may be ignored or given unpredicted weight. Section III attempts to synthesize the most relevant common law factors into a clear rule; the purpose here is to explain the factors and the reasoning behind them.

\section{Pre-existing relationship to the corporation.}

If the corporation can show that it had already established a "beachhead"11 in the opportunity at the time that the participant appropriated it, then under the common law the court would very likely find that the opportunity belongs to the corporation. ${ }^{12}$ Such a pre-existing foothold might take the form of prior negotiations, ${ }^{13}$ a corporate mandate to the participant to find such an opportunity, ${ }^{14}$ or a contractual right (such as an option to purchase). ${ }^{15}$ Some cases have given weight to the intent of the offeror to make the opportunity available to the participant herself rather than to the corporation through the participant. A Missouri court explained:

If, however, a business opportunity is presented to an officer in his individual capacity, rather than in his official capacity as an officer or director, the opportunity is that of the officer and not that of the corporation. ${ }^{16}$

In general, the determinative question is whether there was a pre-

${ }_{11}$ Miller $v$ Miller, 301 Minn 207, 222 NW2d 71, 79 (1974).

12 Under the Miller test, once a corporate opportunity is found, the defendant participant is then left with the difficult task of showing that the transaction was fair to the corporation. Id at 82 .

${ }^{13}$ See, for example, Production Finishing Corp. v Shields, 158 Mich App 479, 405 NW2d 171, 174 (1987) (liability found where corporation had actively pursued the opportunity taken by the director).

14 See Guth, 5 A2d at 503.

${ }^{15}$ News-Journal Corp. $v$ Gore, 2 S2d 741, 744 (1941) (liability found where corporation was lessee of lot that majority stockholders purchased).

${ }^{16}$ Chemical Dynamics, Inc. $v$ Newfeld, 728 SW2d 590, 593 (Mo App 1987), citing Paulman $v$ Kritzer, 74 Ill App 2d 284, 219 NE2d 541, 546 (2d D 1966). 
existing nexus between the corporation and the opportunity. ${ }^{17}$

\section{Opportunities of special value to the corporation.}

When an opportunity has characteristics making it unusually valuable to a corporation, the courts usually find that the opportunity "belongs" to the corporation. ${ }^{18}$ Most cases imposing liability involve opportunities that are either uniquely valuable to the corporation, essential to the corporation, or are guaranteed to produce a profit.

First, many corporate opportunity cases involve disputes over entitlement to unique opportunities like patents or land that have a "special and unique value" to the corporation. ${ }^{10}$ Recall that in Guth, the opportunity at issue was Pepsi Cola's "secret formula"-clearly of unique value to a soda fountain company. In Irving Trust Co. $v$ Deutsch, ${ }^{20}$ the defendant was potentially liable for purchasing a company which owned patents that were of value to the corporation. In Kaufman $v$ Wolfson, ${ }^{21}$ the court denied recovery because it found that the opportunity to buy stock shares was not unique.

Second, courts are more willing to find a corporate opportunity when it appears that the opportunities are essential to the success of the corporation. ${ }^{22}$ To a distribution company, for example, acquisition of one retail store among many choices would not be essential, but acquiring some adjacent real estate for future expansion might be. Whether an opportunity is essential may also be

17 Some courts have required that this pre-existing interest be substantial. See, for example, Pioneer Oil \& Gas Co. v Anderson, 168 Miss 334, 151 S 161, 164 (1933) (prior negotiations and "mere hope or desire" deemed insufficient expectancy); Katz Corp. v T.H. Canty and Co., Inc., 168 Conn 201, 362 A2d 975, 979 (1975) ("plaintiff has failed to establish that the corporation had an avowed business purpose" of acquiring the opportunity).

${ }_{18}$ But see Orchard v Covelli, 590 F Supp 1548, 1554 (W D Pa 1984), aff'd without op, 802 F2d 448 (3d Cir 1986) (discussed in note 37). The corporation's restaurant franchises expired, and the franchisor granted the franchises to the dominant director. Although the franchises were both unique and essential, the court found no misappropriation of corporate opportunities. This may be explained by the fact that the court went on to impose liability based upon the theory that "squeeze out" attempts constitute inherent breaches of fiduciary duty.

19 Litwin v Allen, 25 NYS2d 667, 686 (Sup Ct 1940).

2073 F2d 121 (2d Cir 1934).

21153 F Supp 253, 256 (S D NY 1957).

${ }^{22}$ Johnston v Greene, 35 Del Chanc 479, 121 A2d 919, 923 (Sup Ct 1956) (refusing recovery because the opportunity was not essential); Irving Trust, 73 F2d at 122 (noting that the patents were essential); News-Journal Corp. $v$ Gore, 147 Fla 217, 2 S2d 741, 744 (1941) (property was "extremely valuable" to the corporation). On opportunities "necessary" or "essential" to the corporation, see also, Note, Corporate Opportunity in the Close Corporation-A Different Result?, 56 Georgetown L J 381, 385-386 (1967). 
related to whether it is unique. For example, suppose that a participant buys a fleet of a certain type of used truck from a defunct competitor. This opportunity seems unique in that no similar opportunity is available to the corporation if the participant takes it. The trucks also may be essential if the corporation needs to expand its fleet but cannot realistically afford brand new trucks. Under common law doctrine, the participant probably could not take such an opportunity without first offering it to the corporation.

The courts often do not specify when an opportunity is essential to a corporation, but one strong indication that an opportunity is not essential is a finding that the corporation had an actual or perceived policy against expanding corporate interests into the particular area at issue. In American Investment Co. of Ill. $v$ Lichtenstein, for instance, the court seemed to base its conclusion that the opportunity was not essential on the finding that American had a policy against purchasing minority interests in any company. ${ }^{23}$

A third criterion that courts look to in determining whether an opportunity has "special value" to the corporation is the opportunity's chance of success. Courts are more likely to find that opportunities with low risks of failure should belong to the corporation. This makes sense for a number of reasons. First, it is quite possible that a participant did not involve the corporation in the opportunity precisely because of its speculative nature, choosing instead to risk her own money. Second, when an investment is speculative, the challenging shareholders are in a position to behave opportunistically. If, for example, a corporate participant invests in several related high-risk opportunities, most of which fail and only one of which succeeds, the corporate claimants will naturally pursue only the successful investment.

For these reasons, some courts have declined to turn opportunities over to the corporation in cases of speculative investments by insiders. ${ }^{24}$ In Pergament $v$ Frazer,${ }^{25}$ for example, the dominant

${ }^{23} 134$ F Supp 857, 862-863 (E D Mo 1955). See also Equity Corp. v Milton, 43 Del Chanc 160, 221 A2d 494, 497 (Sup Ct 1966) for the proposition that established corporate policy can waive an opportunity. Contrast this with Irving Trust, 73 F2d 121, where the corporation sent the director out in search of the opportunities. See also Production Finishing Corp., 405 NW2d at 174, finding liability where corporation had actively pursued the opportunity taken by the director.

24 See New v New, 148 Cal App 2d 372, 306 P2d 987 (1957) (oil drilling deemed too speculative; corporation lacked financial ability; third parties refused to deal with the corporation). 
director of the plaintiff corporation formed a new company, Kaiser Aluminum, in order to compete with then monopolist Alcoa Aluminum. The court noted that the new venture was "very risky and possibly very disastrous," and subsequently found that the venture was not an opportunity of the plaintiff company. ${ }^{26}$ Although the reasoning supporting the speculative investment exception seems powerful, very few courts have emphasized the argument.

\section{Feasibility of corporate action.}

Another factor courts use to determine whether an opportunity "belongs" to the corporation is whether the corporation was capable of taking that opportunity when it was offered to the participant. "Where the corporation is unable to avail itself of the business opportunity, there can be no usurpation of a corporate opportunity."27

Corporate inability may take two forms: financial inability or refusal of third parties to deal with the corporation. Some scholars have rejected both the financial inability and unwillingness to deal arguments:

[I]f financial disabilities or third-party refusals to deal with the corporation are accepted as tests, the inevitable result will be to permit the diversion. This is true because courts must resolve the legal issues on the basis of a set of facts within the control of the diverter. ${ }^{28}$

That is, the participant is closest to both the opportunity and the corporation, making it difficult for others to prove that corporate action was feasible.

For good reasons, courts have refused to allow financial inability alone to justify a participant's appropriation of an opportunity otherwise available to the corporation. In Irving Trust Co. $v$ Deutsch, in fact, the court took the position that financial inability never absolves a director. ${ }^{29}$ In Irving Trust, the directors actually created the financial inability by failing to repay debts that they owed to the corporation. The court could have rested its decision

${ }^{25} 93$ F Supp 13 (E D Mich 1950), aff'd as Masterson v Pergament, 203 F2d 315 (6th Cir 1953).

${ }^{28}$ Id at 43.

${ }_{27}$ Robinson $v$ Brier, $412 \mathrm{~Pa} 255,194$ A2d 204, 206 (1963) (emphasis in original).

${ }_{28}$ Brudney and Clark, 94 Harv L Rev at 1021 (cited in note 1).

29 "If the directors are uncertain whether the corporation can make the necessary outlays, they need not embark it upon the venture; if they do, however, they may not substitute themselves for the corporation any place along the line. . ." $73 \mathrm{~F} 2 \mathrm{~d}$ at 124 . 
on those narrow grounds, but instead set forth a broad rule applicable in all cases:

If directors are permitted to justify their conduct on such a theory, there will be a temptation to refrain from exerting their best efforts on behalf of the corporation since, if it does not meet the obligations, an opportunity of profit will be open to them personally. ${ }^{30}$

This rule makes sense in many cases. If the corporation's financial inability is due to mismanagement, in which case creditors would be reluctant to lend even for a promising opportunity, then the participant who played a role in the mismanagement should be estopped from claiming inability of the corporation. Otherwise, a corporation should in theory be able to obtain financing for an opportunity based upon the value of the opportunity regardless of the stability of the corporation. More precisely, if a corporation's financial inability is simply due to its small size or a cash flow problem, the promising nature of an opportunity should suffice to entice creditors.

Nonetheless, where the value of an opportunity depends heavily upon the ability of the individual participant, creditors may demand a personal guarantee from that party. For example, in A.C. Petters Co. $v$ St. Cloud Enterprises, ${ }^{31}$ the court accepted an argument of financial inability where the corporation's bank refused to extend further credit to the corporation unless the defendant director guaranteed any loans. The corporation itself was unable to obtain financing because it was delinquent in the payment of many accounts. The officers formed their own corporation and purchased a parcel of land needed by the corporation in order to keep the land in friendly hands. The court, in holding that no misappropriation of a corporate opportunity had occurred, stated: "It is a universal common-law rule that a corporate officer has no specific duty to use or pledge his personal funds to enable the corporation to take advantage of a business opportunity."32

Thus, despite Irving Trust, courts consistently recognize financial inability as at least a factor ${ }^{33}$ and sometimes as disposi-

so Id.

31301 Minn 261, 222 NW2d 83 (1974).

${ }^{32}$ Id at 86. See also Hart $v$ Bell, 222 Minn 69, 23 NW2d 375, 382 (1946); Three G Corp. v Daddis, 714 P2d 1333, 1336 (Colo App 1986); see also Harry G. Henn and John R. Alexander, Laws of Corporations $\S 237$ at 636 (West, 3d ed 1983).

${ }^{33}$ See Guth, 5 A2d at 511; Paulman 219 NE2d at 546, Morad $v$ Coupounas, 361 S2d 6, 9 (Ala 1978) ("one of the factors to be considered . . . is the corporation's financial ability to 
tive. ${ }^{34}$ However, given courts' differing interpretations of the financial condition that constitutes inability, using this factor to predict outcomes remains difficult. ${ }^{35}$

Even when a corporation is financially able to assume an opportunity, its participation might be frustrated by a third party's unwillingness to deal with it. Older cases often treated the refusal of offerors to deal with the corporation as a form of inability that validated a participant's individual action. ${ }^{36}$ More recent cases have changed course, however, reasoning that if third parties show an unwillingness to deal with the corporation, participants should disclose this fact and attempt to cure the problem:

For the reason that the firmness of a refusal to deal cannot be adequately tested by the corporate executive alone, it has not been favored as a defense unless the refusal has first been disclosed to the corporation. Without full disclosure it is too difficult to verify the unwillingness to deal and too easy for the executive to induce the unwillingness. ${ }^{37}$

undertake the new enterprise, although financial ability must be carefully considered and will not necessarily be determinative"). See also News-Journal Corp. $v$ Gore, 2 S2d at 74445.

${ }^{34}$ See Solimine v Hollander, 128 NJ Eq 228, 16 A2d 203, 215; Jasper v Appalachian

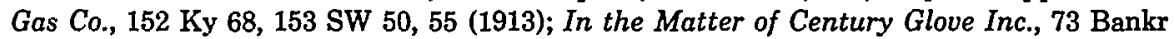
528, 537 (Bankr D Del 1987).

ss In two cases, mere insufficiency of cash on hand supported a finding of financial inability. In Gauger $v$ Hintz, the court stated: "[T]he corporation did not have the liquid funds available .... [D]efendants might have borrowed the money, but they were opposed to going in debt." 262 Wis 333, 55 NW2d 426, 436 (1953). In Katz Corp. v T.H. Canty and Co., the court observed: "Its cash on hand and liquid assets were insufficient to enable it to make such a substantial purchase. There can be no expectancy in a transaction unless the corporation is financially able to undertake it." 362 A2d at 980 . Other courts, however, have required a greater showing of inability. See, for example, Nicholson $v$ Evans, 642 P2d 727, 731-32 (Utah 1982).

so See New, 306 P2d at 996; Seal-O-Matic Machine Mfg. Co. v C\&M Eng. \& Mfg., 21 NJ Super 311, 91 A2d 173, 175 (1952); Pioneer Oil \& Gas Co., $151 \mathrm{~S}$ at 163.

${ }^{37}$ Energy Resources Corp., Inc. v Porter, 14 Mass App 296, 438 NE2d 391, 394 (1982). In Energy Resources, Porter, an officer, developed an energy research project in conjunction with Jackson, a party outside the corporation. Porter, on behalf of Energy Resources, sought a government grant together with Jackson. When Jackson refused to deal with Energy Resources, Porter resigned and together they obtained the government grant for the project. Since the party refusing to deal with the corporation was Porter's friend and colleague, the defense was especially difficult to test in this case. See also Production Finishing Corp., 405 NW2d at 175. (court explicitly rejects the unwillingness-to-deal defense in the absence of disclosure of the refusal to the corporation). These cases can be contrasted with the federal district court's decision in Orchard v Covelli, 590 F Supp 1548 (W D Pa 1984), allowing an expansive defense based on refusal of third parties to deal with the corporation. The plaintiff and defendant were codirectors of corporations that owned several McDonald's franchises. When the franchises came up for renewal, McDonald's offered to renew them in Covelli's name alone, thereby excluding the corporations, and, in particular, Orchard, whose 
If a participant's sole argument is that the corporation could not have taken the opportunity in question either because it lacked the funds or the good will of the party offering the opportunity, then the court should probably require that the participant show full disclosure prior to diverting the opportunity. This protects the corporation by giving other participants a chance to exert their best efforts to secure financing or convince third parties.

\section{Corporate waiver of the opportunity.}

Under the common law, certain actions by the corporation, such as consent, implied rejection, and ratification, are deemed to waive the corporation's right to object to a participant's individual use of a corporate opportunity. First, the corporation may consent to a pattern of outside investment by participants. In Burg $v$ Horn, for example, the defendants, directors and stockholders of the Darand Corporation, "already owned corporations holding similar properties when Darand was formed."38 Because the complaining participant knew this, the court declined to infer a duty to offer Darand all such properties coming to the directors' attention. In an industry where outside but related investments commonly occur, it makes sense for the participants in a small business to consent to such investments. As the Burg court noted, "a person's involvement in more than one venture of the same kind may negate the obligation which might otherwise be implied to offer similar opportunities to any one of them." 3

Just as the corporation may consent to a participant's individual action by permitting a pattern of outside investment, it may also consent by explicitly or implicitly rejecting the opportunity. The "evil" necessitating the corporate opportunity doctrine is "a fiduciary diverting or usurping a corporate opportunity without the corporation having the opportunity to first act."40 Therefore,

conduct had displeased McDonald's. Because McDonald's had exclusive discretion in choosing to whom it would award the franchise, the court found no usurpation of a corporate opportunity. Id at 1554. The court reached this decision even though "Covelli failed to use his best efforts to procure the continued life of the existing franchises in the names of the corporations." Id at 1558. The court ultimately found that Covelli had breached his fiduciary duty based on a squeeze out doctrine, id at 1557-1558, thus minimizing the force of the decision on the corporate opportunity issue. The Orchard court's application of the corporate opportunity doctrine does not represent the typical common law approach.

${ }^{38} 380$ F2d at 900 . The director in Burg purchased homes for himself while serving on the board of a real estate enterprise.

s9 Id at 901 .

${ }^{10}$ Suburban Motors of Grafton, Inc. v Forester, 134 Wis 2d 183, 396 NW2d 351, 355 (Wis App 1986) (emphasis in original). 
if the director first offers the opportunity to the corporation with full disclosure and the disinterested board members reject the opportunity, then the director may take it. Such a formal rejection always constitutes a defense.

In some cases a formal rejection is unnecessary. ${ }^{41}$ If the participant can show that other participants knew about the opportunity, yet failed to act upon it, then the court might find that the other participants rejected the opportunity by implication.

A third instance of waiver occurs if the corporation "ratifies" the participant's actions. If a corporation fails to act immediately after learning of a participant's use of an opportunity, that inaction might constitute implicit ratification. Provided such a ratification is by disinterested directors of an undominated board, or by disinterested shareholders, it might estop the corporation from bringing a claim for usurpation of corporate opportunity. ${ }^{42}$ However, ratification requires that the company and disinterested management be aware of all the material facts. Hence full and formal disclosure may be necessary in any event. ${ }^{43}$

\section{B. The Common Law Tests}

Courts have considered the preceding factors in judging corporate opportunity under the common law. These factors represent the intuitions underlying the doctrine of corporate opportunity. Not surprisingly, they figure prominently in this comment's suggested approach. Nonetheless, courts' haphazard application of these factors has sown confusion in the law.

In an attempt to add some coherence to the use of the common law factors, courts have developed three tests to determine when the nexus between a corporation and an opportunity transforms a general business opportunity into a corporate opportunity: (1) whether the corporation has an interest or expectancy in the

1 See Litwin, 25 NYS2d at 691 ("The directors' vote recording this fact, although desirable, would have been a formality, the absence of which should not affect the rights of the parties."). See also Lussier v Mau-Van Development, Inc. I, 4 Hawaii App 359, 667 P2d 804,813 (1983). In Lussier, the director stated at a shareholders meeting that an option on certain parcels was running out and if the corporation could not come up with the money, he would take the opportunity. The court found that the shareholders subsequent failure to object constituted implied consent.

${ }^{12}$ In Re Central Pacific Boiler \& Piping, Ltd., 81 Bankr 40 (Bankr D Hawaii 1987) (court allowed defendant to borrow money on corporation's line of credit in order to obtain the challenged opportunity where corporation knew of the practice and defendant had personally guaranteed credit).

is Durfee v Durfee \& Canning, 323 Mass 187, 80 NE2d 522, 531 (1948). 
opportunity; (2) whether the opportunity falls within the corporation's line of business; and (3) whether considerations of fairness dictate that the corporation should have the opportunity.

Under the interest or expectancy test, an opportunity is open to the director unless the corporation has an "interest already existing [in the opportunity], or ... it has an expectancy growing out of an existing right." "4h this test does not bar directors from every transaction that appears useful to the corporation in hindsight, but only prevents "their acquisition of property which the corporation needs or is seeking." 45

The line of business test holds that a transaction is a corporate opportunity if it is "within the scope of [the corporation's] own activities and of present or potential advantage to it. . .."46 Under this test, corporate participants must refrain from taking for themselves the types of transactions in which their corporation normally engages. ${ }^{47}$

Some courts have dispensed with both tests and treated the issue as an amorphous question of fairness. ${ }^{48}$ This may actually be the most candid approach to the problem since all the cases in the area seem to involve a rather subjective juggling of a long list of factors. But, while a fairness test recognizes the inherently subjective nature of the present corporate opportunity doctrine, it fails to provide corporate participants with the guidance they need.

44 Lagarde v Anniston Lime \& Stone Co., 126 Ala 496, 28 S 199, 201 (1900). "The rule . . . is not satisfied by proof that after the property is appropriated it occurs that it would have been useful in the corporation's business." Blaustein v Pan American Petroleum \& Transport Co., 293 NY 281, 56 NE2d 705, 713 (1944).

is Burg, $380 \mathrm{~F} 2 \mathrm{~d}$ at 899 . Other cases employing the interest or expectancy test include: In the Matter of Century Glove, Inc., 73 Bankr 528 (officer personally bought a shipment of full-fashion gloves, but court found no corporate opportunity because the corporation was financially incapable of buying gloves and corporation had no interest in expanding from work gloves into full-fashion gloves); Three G Corp., 714 P2d at 1336 (despite Three G's contractual right in the property, purchase of property was not within "expectancy" of company due to its financial condition); Orchard, $590 \mathrm{~F}$ Supp at 1554 ("Absent any entitlement, Covelli cannot be said to have usurped a corporate opportunity over which the corporations had little control"); United Seal and Rubber Co., Inc. v Bunting, $248 \mathrm{Ga} 814,285$ SE2d 721 (1982) (the court found no corporate opportunity when directors in a highly competitive industry resigned and took customers with them); Pergament, 93 F Supp at 43.

46 Lutherland, Inc. v Dahlen, 357 Pa 143, 53 A2d 143, 147 (1947).

${ }^{47}$ See, for example, Energy Resources Corp., Inc., 438 NE2d 391 (finding breach of duty where officer developed an energy research project while working for an energy research corporation, on corporation time with corporate assets, and secretly diverted the opportunity to himself); Harper $v$ Superior Tool and Die Co., 1987 WL 18414 (ED Pa) (finding a breach of duty where two of the three participants diverted the most lucrative portion of the family business to their own corporation).

18 See Durfee, 80 NE2d at 528; Paulman, 219 NE2d at 546. 
In order to add some coherence and predictability to the fairness test, the Minnesota Supreme Court adopted a two-step approach in the oft-cited case of Miller $v$ Miller. ${ }^{40}$ The court grouped the relevant factors under two questions: (1) was the challenged transaction an opportunity for the claiming corporation? (a line of business approach is used); (2) If so, did the officer/director act unfairly when she took the opportunity?

\section{Critique of the Common Law Tests}

Each of the above three tests represent attempts to identify and consolidate the most significant factors used in the various corporate opportunity cases. Yet it is partly because the courts' tests of corporate opportunity invite consideration of all the usual common law factors that they fail to add coherence to the law: application of the tests varies from state to state, resulting in continued inconsistent and unreliable use of the underlying factors.

Perhaps more importantly, there are problems inherent in the tests themselves. The line of business test eludes definition and bears only a questionable relevance to the objectives of the corporate opportunity doctrine. First, the scope of a corporation's business may be indefinite, and opportunities on the margin will pose impossible problems of categorization. Second, it is not clear why a corporation should be restricted to its current line of business even if a line of business can be defined. If a joint venturer is bringing suit to recapture an opportunity that he feels belongs to the corporation, then that fact alone suggests a desire of the corporation to expand into that area of business. It seems irrelevant that the corporation has not previously operated in that field. If, in the alternative, prospective lines of business are limitless, as they seem to be, then the notion becomes meaningless and should be abandoned.

Although the existence of a corporate interest or expectancy in the opportunity has some relevance to the question of liability, it hardly disposes of the issue single-handedly. Therefore, courts

4 $222 \mathrm{NW} 2 \mathrm{~d}$ at 81 . In Miller, the directors of a closely held corporation organized other companies (without using corporate funds) to handle tasks that the corporation lacked the facilities to undertake. Both the corporation and the spin-off companies profited by the arrangement. In dismissing the complaint of persons holding a remainder interest in stock, the court found that the directors did take business opportunities but held that the takings were fair. See also Cannon Oil \& Gas Well Service, Inc. v Evertson, 836 F2d 1252, 1255 (10th Cir 1987); Southeast Consultants, Inc. v McCrary Eng. Corp., 246 Ga 503, 273 SE2d 112,117 (1980) (adopting a modified version of the Miller test, using interest/expectancy as the first prong). 
should consider corporate interest or expectancy in the opportunity as only one factor in the overall analysis of fiduciary duty. ${ }^{50}$

In linking liability to opportunities "belonging" to the corporation, the two tests show vestiges of the antiquated notion that an opportunity is a corporate asset that the defendant has stolen. ${ }^{51}$ But no sound principle requires that a corporation limit itself to a rigid category of investments that it in some sense owns. The better view is that every opportunity constitutes a business opportunity. In other words, given the diversity of interests possible and the desirability of expanding into new fields, courts should presume that corporations consider every business activity an opportunity. ${ }^{52}$ The question is not one of ownership, but whether the corporate participant may take the opportunity as an individual without breaching her duty of loyalty. The issue is not misappropriation, but misbehavior.

\section{The ALI Principles of Corporate Governance}

A. The Application of Sections 5.05 and 5.12

The American Law Institute has included a reformulation of the corporate opportunity doctrine in its corporate governance project. Section 5.05 of the ALI states in pertinent part:

§ 5.05 CORPORATE OPPORTUNITIES(a) General Rule. A director $[\S 1.08]$ or senior executive $[\S 1.28]$ may not take advantage of a corporate opportunity unless:

(1) he first offers the corporate opportunity to the corporation and makes disclosure concerning the ... corporate opportunity $[\S 1.09(\mathrm{~b})]$;

(2) the corporate opportunity is rejected by the corporation; and

(3) (A) the rejection of the opportunity is fair to the corporation; or

(B) the rejection is authorized, following such disclosure,

so This test may be captured in the notion of pre-existing relationship. See text accompanying notes 11-16.

${ }^{11}$ This notion persists in modern cases. For example, in 1987 the Nevada Supreme Court stated: "It is also generally recognized that a corporate fiduciary cannot exploit an opportunity that belongs to the corporation. The difficulty arises, however, when attempting to ascertain if a particular opportunity 'belongs' to the corporation." Leavitt v Leisure Sports Incorporation, $103 \mathrm{Nev} 81,734$ P2d 1221, 1225 (1987).

${ }^{82}$ The Utah Supreme Court seems to take this view of corporate opportunities: "[The corporate opportunity doctrine] applies to whatever could be of value to the enterprise to which the fiduciary owes a duty." Nicholson v Evans, 642 P2d 727, 731 (Utah 1982). 
by disinterested directors [ $\$ 1.10]$, in a manner that satisfies the standards of the business judgment rule [\$ 4.01(c)]; or

(C) the rejection is authorized or ratified by disinterested shareholders [\$1.11], following such disclosure, and the shareholders' action is not equivalent to a waste of corporate assets [§ 1.34].

(b) Definition of a Corporate Opportunity. For purposes of this Section, a corporate opportunity means:

(1) any opportunity to engage in a business activity of which a director or senior executive becomes aware either:

(A) in connection with the performance of his functions as a director or senior executive, or under circumstances that should reasonably lead him to believe that the person offering the opportunity expects him to offer it to the corporation; or

(B) through the use of corporate information or property, if the resulting opportunity is one that the director or senior executive should reasonably be expected to believe would be of interest to the corporation; or

(2) any opportunity to engage in a business activity of which a senior executive becomes aware, if he knows or reasonably should know that the activity is closely related to the business in which the corporation is engaged or may reasonably be expected to engage. A "business activity" includes the acquisition or use of any contract right or other tangible or intangible property. ${ }^{53}$

At this time, the ALI's corporate opportunity rule is only part of a tentative draft, but it has been adopted by the courts of Oregon and Tennessee. ${ }^{54}$ The Principles of Corporate Governance, as the name suggests, covers a broad range of corporate issues concerning all types of corporations. ${ }^{\mathrm{BS}}$ Understandably, however, the Project approaches most questions from the perspective of the large, publicly-held corporation. Consequently, in keeping with the structure

${ }^{63}$ ALI Project at 104-06 (cited in note 2).

st Klinicki $v$ Lundgren, 298 Or 662, 695 P2d 906, 917-18 (1985); Tennessee Bearing \& Supply, Inc. v Parrish, 1988 WL 122337 (Tenn App).

ss The ALI avoided using the term "Restatement" because the drafters intended to create something more normative than a traditional restatement of existing law. A. A. Sommer, Jr., The Duty of Loyalty in the ALI's Corporate Governance Project, 52 Geo Wash L Rev 719,725 (1984). Sommer suggests, however, that the corporate opportunity section is "in large measure a restatement of portions of the corporate common law in the truest ALI sense." Id at 737. See also Kenneth E. Scott, Corporation Law and the American Law Institute Corporate Governance Project, 35 Stan L Rev 927, 929 n 9 (1983) ("The document is in no sense a simple restatement of the existing law in the area."). 
of public corporations, the ALI proposal varies the degree of fiduciary duty in the corporate opportunity context according to the participant's role in the corporation.

The "overwhelming majority" of corporate opportunity cases, however, involve closely held corporations ${ }^{56}$ where the same individuals are often officers, directors, and shareholders. ${ }^{57}$ As a result, the ALI corporate opportunity rule will, in practice, impose on all corporate participants the same strict requirement of full disclosure and formal rejection.

\section{Who is covered?}

The ALI Project recognizes the need to allow participants to hold outside investments. While $\S 5.05$ sets forth the general rule for officers and directors, $\S 5.12$ provides a more lenient rule for shareholders. ${ }^{58}$ As the Reporter explains:

Section 5.12(b) defines a corporate opportunity more narrowly than $\$ 5.05(b)$, in order to balance the right of the dominating shareholder to engage in business in competition with the cor-

${ }^{58}$ Brudney and Clark, 94 Harv L Rev at 1061 (cited in note 1). Of all the cases cited in this comment, only Pergament v Frazer, 93 F Supp 13 (E D Mich 1950), involved a publicly held corporation.

${ }^{87}$ Frank H. Easterbrook and Daniel R. Fischel, Close Corporations and Agency Costs, 38 Stan L Rev 271, 273 (1986); Comment, Exploitation Among Close Corporation Shareholders: A Philosophical Change and its Consequences, 16 Land \& Water L Rev 747, 754 (1981).

Bs $\S 5.12$ states:

CORPORATE OPPORTUNITIES

(a) General Rule. A dominating shareholder [\$1.12] may not take advantage of a corporate opportunity unless:

(1) The taking of the opportunity is fair to the corporation; or

(2) The taking of the opportunity is authorized or ratified by distinct shareholders [\$1.11], following disclosure concerning the conflict of interest [\$1.09(a)] and the facts concerning the corporate opportunity [1.09(b)], and the shareholders' action is not equivalent to a waste of corporate assets [\$1.34].

(b) Definiton of Corporate Opportunity. For purposes of this Section, a corporate opportunity means any opportunity to engage in a business activity that is held out to shareholders of the corporation as being within the scope of the business in which the corporation is presently engaged or may be reasonably expected to engage, and that is neither developed nor received by the dominating shareholder within the scope and regular course of his own business activities. "A business activity" includes the acquisition or use of any contract right or other tangible or intangible property.

(c) Burden of Proof. A party who challenges the taking of a corporate opportunity has the burden of proof, except that the dominating shareholder has the burden of proving that the taking of the opportunity is fair to the corporation if the taking of the opportunity was not authorized or ratified by disinterested shareholders, following the disclosure required by Subsection (a)(2).

ALI Project at 184-85 (cited in note 2). 
poration against the need to assure that the dominating shareholder does not seize for himself opportunities that could fairly be said to belong to the corporation. ${ }^{59}$

A dominant shareholder who is also a director or senior executive is governed by $\S 5.05$ and not $\S 5.12 .^{60}$ Since shareholders in close corporations usually also hold management positions, $\S 5.05$ will govern virtually all close corporation cases.

Section 5.05 itself also distinguishes between certain roles in a corporation. The drafters noted that the need to encourage outside directors who may have multiple business activities justifies a distinction between directors in general and directors who are senior executives. $^{61}$ Section 5.05(b)(1) defines corporate opportunities somewhat narrowly with respect to directors, employing two common law factors. ${ }^{62}$ In contrast, $\S 5.05(b)(2)$ defines corporate opportunity very broadly for senior executives, a term defined most recently in Tentative Draft Number 2. The term is defined broadly, encompassing the president, treasurer, secretary, controller, vice presidents with policy functions, and the "chief executive, operating, financial, legal, and accounting officers of the corporation." ${ }^{33}$ In a closely held corporation, virtually every participant will hold some significant position, have some title, or perform some function that will qualify her as a senior executive and require her to meet the more stringent requirements of $\S 5.05(\mathrm{~b})(2)$.

s9 Id at 186.

so Id at 187.

61 Id at 109 (comments to $\S 5.05$ ).

${ }^{62}$ Section $5.05(\mathrm{~b})(1)(\mathrm{A})$ reflects the common law factor that the corporation is entitled to those opportunities that it is reasonable to believe the offeror intended to make available to the corporation. Id at 104-05. See Chemical Dynamics, Inc., 728 SW2d 590. Section $5.05(b)(1)(B)$ restates the principle that any use of corporate assets to obtain an opportunity for the benefit of the director constitutes a clear violation of the doctrine. Note, 56 Georgetown L J at 384 (cited in note 22); Guth, 5 A2d at 510-11; Solomine, 16 A2d at 220.

${ }^{3}$ American Law Institute, Principles of Corporate Governance 11, 14 (Tentative Draft No. 2) (ALI 1984) includes the following definitions:

$\S 1.25$ Senior Executives

"Senior executives" means the officers described in $\S \S 1.19(1)$ and (2).

$\S 1.19$ Officer

"Officer" means (1) the chief executive, operating, financial, legal, and accounting officers of a corporation; (2) to the extent not encompassed by the foregoing, the chairman of the board of directors (unless the chairman neither performs a policymaking function other than as a director, nor receives a material amount of compensation in excess of director's fees), president, treasurer, secretary, and controller, and a vice-president who is in charge of a principal business unit, division, or function (such as sales, administration, or finance) or performs a major policymaking function for the corporation .... 


\section{Which opportunities are covered?}

Due to the breadth of the "Definition of a Corporate Opportunity," almost any business transaction will be subjected to the blanket disclosure and rejection requirement of $\S 5.05(\mathrm{a})$ :

Section 5.05(b) covers as broadly as possible any type of contract or property right or activity that could reasonably be expected to be of benefit to the corporation, subject only to limitation by $\S \S 5.05(\mathrm{~b})(1)$ and $5.05(\mathrm{~b})(2) .^{64}$

The comment to $\S 5.05(\mathrm{~b})(2)$ states that the ALI intended to adopt "essentially the standard enunciated by the Supreme Court of New Hampshire in Rosenblum v. Judson Engineering Corp." In Rosenblum, the New Hampshire Supreme Court extended the definition of line of business to include not only the corporation's present activities, but those "closely associated" activities which the corporation prospectively might want to undertake in the future. ${ }^{66}$

Since Rosenblum involved a business prospect that was new but closely related to the corporation's current business, courts could give the rule in that case two conflicting interpretations. On the one hand, courts could read the rule narrowly and only impose the requirements of $\S 5.05$ (a) when the opportunity related to existing activities or activities within the contemplated future of the corporation as judged by the corporation's present activities. Such a standard, however, is subject to the same criticisms as the traditional line of business test. If a new and totally different business activity looks profitable, then the corporation would probably want a chance to engage in it. $^{67}$

On the other hand, the courts may read Rosenblum to mean that the scope of the corporation's present business is largely irrelevant. Such a reading renders pointless $\S 5.05(\mathrm{~b})(2)$ 's language referring to an activity "closely related to the business" and means that almost every business transaction will be a corporate

64 ALI Project at 112 (comments to $\S 5.05$ ) (cited in note 2).

${ }^{65}$ Id at 117.

${ }^{68}$ Rosenblum $v$ Judson Engineering Corp., 99 NH 267, 109 A2d 558, 563 (1954). The ALI Project states that the rule "not only does not limit the doctrine's applicability to a particular 'line of business,' but applies the doctrine to a contemplated activity in which the corporation may subsequently engage." ALI Project at 117 (comments to $\$ 5.05$ ) (cited in note 2). Rosenblum involved a close corporation that manufactured automobile wheel aligners. Three of the four director-shareholders, in anticipation of a license to produce wheel balancers, formed a separate partnership to manufacture and sell the device. The court found the participants liable for not offering the opportunity to the corporation.

${ }^{67}$ See text accompanying notes 22-23. 
opportunity.

Notwithstanding this language in $\S 5.05(\mathrm{~b})(2)$, the ALI Reporter apparently intended to endorse a very broad definition of corporate opportunity. This is the reading of the ALI rule that this comment will adopt, as it comports with the general theme of the ALI rule:

Section 5.05 sets forth a comprehensive statement of the doctrine of corporate opportunity which generally requires an opportunity that could be advantageous to the corporation to be offered by a senior executive to the corporation before he takes it for himself. ${ }^{68}$

Realistically, corporations will only file lawsuits to recover the profitable opportunities that participants appropriated as individuals. Those opportunities, therefore, will almost always be opportunities that "could be" advantageous to the corporation. Since virtually every close corporation participant is likely to fall within the definition of a senior executive, the ALI rule will foreclose practically all opportunities to such participants unless they comply with the disclosure and rejection requirements examined below.

3. The impact of finding a corporate opportunity.

If a business transaction falls within $\S 5.05(\mathrm{~b})$-and the above discussion indicates that almost every challenged transaction will-then $\S 5.05$ (a) imposes a strict requirement of full disclosure and rejection before a participant may enter the transaction as an individual. According to one commentator, the disclosure requirements must be viewed in absolute terms:

It should be noted that it is the intent of the Reporter that no failure to offer an opportunity to the corporation can be justified on any grounds, and even a proof that the taking of the opportunity by the director or officer was fair will not suffice for him to avoid liability if it was not offered to the corporation. $^{69}$

Although the ALI imposes a bright line rule of mandated disclosure, it seems that it is not necessary for a participant to receive an actual vote of rejection before taking an opportunity for herself. The comments to $\S 5.05$ (a) state: "Failure to accept the opportu-

68 ALI Project at 107 (cited in note 2).

69 Sommer, 52 Geo Wash L Rev at 742 (cited in note 55). 
nity promptly will be considered tantamount to a rejection." Thus, implied rejection seems possible under the ALI rule. Nonetheless, where there is such a rejection by inaction of the disinterested directors, courts still must make an inquiry as to the validity of this ratification under $\$ 5.05$ (a)(3). This section requires that the participant who took advantage of the opportunity establish the fairness of the implied rejection. ${ }^{71}$ As a result, it would seem that courts must dive into the same confusing, disorganized body of common law fairness factors that the ALI rule sets out to avoid. Indeed, the ALI rule may ultimately create more confusion by requiring a fairness analysis without providing clear guidance as to how various factors should be considered in that analysis. Therefore, if the rule allows for implied rejection of corporate opportunities, the ALI proposal fails to produce the advantage of administrative efficiency that it set out to provide.

Alternatively, when courts adopt the ALI rule they may interpret $\S 5.05(a)$ to require formal rejection by a corporation's directors in all cases. Such an interpretation would make sense given the language of $\$ 5.05(\mathrm{a})$ and the ALI's purpose of providing a clear rule. Rejections would still be tested for either fairness, ${ }^{72}$ authorization by disinterested directors, or authorization by disinterested shareholders, but the rule would clearly amount to a requirement that the participant wishing to take advantage of the opportunity always secure the permission of a majority of the other participants. $^{73}$

70 ALI Project at 109 (cited in note 2).

21 The other options under $\$ 5.05(a)(3)$ would not be available in a case of rejection by corporate inaction. Sections $5.05(a)(3)(B)$ and (C) require, respectively, a rejection by disinterested directors or a ratification of the rejection by disinterested shareholders. In most close corporations, where shareholders and directors are the same people, both of these options will amount to a requirement of formal rejection.

72 For example, if she dominated the board of directors, the challenged participant may be required to show that the rejection was fair. See ALI Project at 104-05 (§ 5.05(a)(3)(B) and (C)) (cited in note 2). Nonetheless, situations involving formal rejections by dominated boards will be a small subset of all the cases lacking a valid formal rejection.

${ }^{73}$ In Klinicki, 695 P2d at 920, the Oregon Supreme Court emphasized that: "The director or principal senior executive may take advantage of the corporate opportunity only after full disclosure and only if the opportunity is rejected by a majority of disinterested directors or, if there are no disinterested directors, by a majority of disinterested shareholders." The case itself involved a clear-cut usurpation of a corporate opportunity, with the defendant using the plaintiff corporation's working time, staff, money, and facilities in order to take the opportunity for himself. Id at 909 . In fact, the only factor that the director asserted in his favor was the financial inability of the corporation, which, the court found, he failed to establish. Given the facts of the case, the Oregon court's adoption of $\S 5.05$ was arguably unnecessary to the decision. 


\section{B. Critique of the ALI Corporate Opportunity Rule}

Imagine that Sue, an entrepreneur owning an interest in several food retail stores, becomes a participant in Acme, a closely held food distributing enterprise. Subsequently, she purchases an interest in Beta, a food retailing enterprise. The other participants in Acme bring an action against Sue to impose a constructive trust on the Beta business.

Under the ALI rule, Sue could have avoided liability by disclosing and obtaining a formal rejection of the Beta opportunity. But there are good reasons why Sue may want to avoid requesting a formal rejection. First, she may wish to avoid disclosure. Perhaps Beta wishes to avoid publicity before the transaction, or Sue may fear that publicity will result in an auction in which she will either pay too much for Beta or lose the opportunity altogether. Disclosure may result in other Acme participants bidding for the opportunity as individuals, "free riding" on Sue's efforts to discover and set up the Beta purchase.

Second, Sue might simply consider disclosure unnecessary. Suppose that in the food industry participants commonly hold outside investments completely independent of the corporation. Acme may fully expect Sue to enter into opportunities like Beta, and Acme may acquiesce in this normal practice when accepting new participants like Sue. Yet, under the ALI Project, Sue and the corporation must unnecessarily bear the transaction costs of formal disclosure.

Third, she may wish to avoid the obligation to obtain formal ratification, fearing opportunistic behavior by other Acme participants. Acme may not want the opportunity, but the other directors or shareholders may withhold consent in order to extract some payment from Sue. Thus, corporate hold outs may either demand payment for their votes before Sue embarks on the opportunity, or demand payment to avoid a suit after she has taken the opportunity.

After some period of time, such corporate non-acceptance will become an "unreasonabl[e] fail[ure] to reject," how long that period is. In that time, Sue may lose the Beta deal. The fear that such delay will ruin the opportunity, and the uncertainty of future litigation, will give "disinterested" participants great leverage in requiring Sue to buy their rejection votes. ${ }^{75}$

74 Id at 920.

${ }^{73}$ As explained above, it is not clear whether courts will interpret the ALI project to 
It is not hard to imagine hold out problems that this rule could create, especially when an ailing corporation is financially unable to take an opportunity that a director wishes to take for herself and the other participants want to force her to buy them out at an inflated price. Conversely, other participants could withhold consent in an effort to force Sue to bail out of the Acme corporation by selling her shares to them at a deflated price. ${ }^{76}$

In addition to the difficulties it engenders for Sue, the disclosure and rejection rule creates moral hazards for disinterested participants. ${ }^{77}$ It may, for example, allow a participant to risk funds on several investments without obtaining a rejection, perhaps believing that rejection is not necessary. Then, when certain of the investments prove to be fruitful, other disinterested participants can claim them for the corporation. ${ }^{78}$ In this way the corporation reaps the benefit without assuming any of the risk.

Another problem with the ALI rule is that close corporation actors with multiple business interests will either have to forego valuable opportunities or face the risk that some minor violation of corporate formalities will expose them to liability. Even if participants have strong reasons for seeking out transactions for the corporation's benefit, the scope of this search will be constricted by the fact that opportunities inappropriate to the corporation will not be available to the individual without considerable risk of liability. Under this regime, many transactions of value to society will remain undiscovered.

Thus, the strict rule creates a powerful disincentive for small businesspeople to participate in closely held corporations, thereby diminishing the value of the closely held corporation as an organizational form. This will also decrease the benefits of cross fertilization that come from participants having input in diverse business ventures. ${ }^{79}$

allow for implied rejection no matter how long rejection is withheld. See text accompanying notes 69-73.

${ }^{76}$ See Easterbrook and Fischel, 38 Stan L Rev at 275-77 (cited in note 57), for an explanation of how lack of an active market in shares can injure investors in closely held corporations.

${ }^{77}$ See id at 285, noting that in organizing a closely held corporation, drafters must be careful not to "give the minority too many rights, for the minority might exercise their rights in an opportunistic fashion. ..."

${ }^{78}$ See, for example, Chemical Dynamics, 728 SW2d at 593 (participant bailed out corporation in default on its rental payments and the corporation subsequently sued him for exercising option to purchase on the lease assignment).

${ }^{78}$ On the value of cross fertilization, see Comment, Miller v Miller-Proper Application of the Fairness Doctrine in the Corporate Opportunity Area, $2 \mathrm{~J}$ Corp Law 405, 416 
The ability to engage in individual transactions is especially important to the small entrepreneur because she may have a role in several close corporations, any one of which may benefit from the opportunity and every one of which may behave stubbornly in tendering a rejection. The ALI addresses the potential conflict, but its "resolution" of this dilemma is unacceptably costly and complex for a small businessperson:

Section 5.05 resolves the dilemma of a senior executive who has the duty to offer a corporate opportunity to more than one corporation by providing him one of three alternatives (1) refrain from offering the opportunity to any corporation ... and not pursue it for his personal benefit; (2) offer the opportunity to each corporation and secure a rejection of the opportunity from each corporation before pursuing it for his personal benefit; or (3) if he is under an obligation ... to pursue the opportunity for one or more of the corporations, to offer the opportunity to the corporation or corporations to whom he owes the duty, in order to satisfy his obligation. . . . The director or senior executive may secure advance rejection from one or more corporations to whom he owes a duty under $\S 5.05$ in favor of another corporation of which he is also a director or senior executive. If he cannot obtain such advance rejection, he should consider terminating his relationship with one corporation or the other to resolve the conflict as to future opportunities. ${ }^{80}$

These supposed solutions will greatly increase the threats of opportunistic behavior presented by any formal rejection requirement.

Section 5.05 will also result in inefficient allocation of resources. Sometimes, the participant will be in a better position than the corporation to utilize the opportunity. Each participant as an individual is better off if she can take the opportunities best suited to her individual business capacities. The corporation as a whole is better off if it can obtain participants at lower cost:

[I]n some instances an opportunity may be worth more to the manager than to the corporation; in that case, both the shareholders and the manager would be made better off if the manager were permitted to avail himself of the opportunity,

(1977).

so ALI Project at 111 (cited in note 2). 
thereby allocating the business opportunity to the manager as a form of compensation and allowing his other forms of compensation to be commensurately reduced. ${ }^{81}$

Admittedly the ALI proposal has the distinct advantage of predictability. ${ }^{82}$ Nonetheless, in a closely held corporation where board meetings are rare and the participants know each other intimately, a formal disclosure and rejection may be pointless, redundant, cumbersome, and needlessly expensive. By adopting a rigid rule and by erring on the side of the corporation, the ALI proposal will increase the cost of finding and retaining small corporation participants. Because the ALI rule threatens to impose these unadvisable burdens on small corporations, this comment proposes a more desirable corporate opportunity rule.

\section{RECOMMENDATIONS}

The rule against usurpation of corporate opportunities should encourage as many beneficial transactions as possible while deterring participants from preferring their interests to the corporation's when the corporation would thereby suffer unfairly. In addition to achieving this balance, corporate opportunity doctrine must be clear enough to be predictable and to guard against lawsuits that the parties do not expect.

Conceptually, the proposed rule differs from the ALI in three major ways. First, the ALI rule approaches the corporate opportunity problem from the standpoint of the large publicly owned corporation. The proposed rule is based on the realities of the close corporation, where most corporate opportunity cases arise. Second, the ALI rule starts from the presumption that all business opportunities that could benefit a corporation must be submitted for rejection and then proceeds to define those limited situations in which a corporate participant may take an opportunity. The proposed rule starts from the presumption that participants are free to engage in independent business activities. Finally, because the ALI rule requires a high duty of loyalty, it operates as a strict mandate and not merely as a background or default rule out of which the parties can contract. In contrast, the proposed rule sets

${ }^{81}$ Comment, Insider Trading at Common Law, 51 U Chi L Rev 838, 842 (1984).

82 "Weighing on the side of the proponents of the ALI's effort is the manifest confusion among corporate lawyers, their clients, litigants, and judges about the doctrines and precepts that should be applied. There is value in certainty and predictability, especially in laws affecting business transactions." Sommer, 52 Geo Wash L Rev at 743 (cited in note 55) (footnote omitted). 
the duty of loyalty lower and then allows parties to contract for a higher fiduciary duty by expressly limiting the ability of participants to engage in outside business activities.

\section{A. A Proposed Rule for Corporate Opportunity}

1. Cause of action.

A participant violates her fiduciary duty of loyalty to a corporation when she engages in a business venture without first offering it to the corporation and obtaining formal rejection if and only if the plantiff participant or corporation shows one of the following two factors:

(1) the corporation had a pre-existing relationship to the opportunity; or

(2) the corporation lacked any independent knowledge of the opportunity and either

(A) the participant failed to disclose both the opportunity and plans to invest therein, ${ }^{83}$

(B) the opportunity was of special value to the corporation because it was unique or essential, or

(C) the corporation had an explicit policy or a clear history of not allowing participants to engage in outside investments.

\section{Affirmative defense.}

When the plaintiff establishes the cause of action, the defendant participant will be liable for failure to offer the opportunity to the corporation and obtain a formal rejection unless the defendant can show:

(1) the defendant disclosed the opportunity to the corporation; and

(2) the defendant had a reasonable belief that the plantiff participants would have withheld rejection in order to extract

${ }^{83}$ Simple disclosure of the name of the investment and the offeror is sufficient. The corporation has the responsibility to investigate further unless the opportunity is one of special value to the corporation or the corporation has a policy against outside investments. This will allow courts to avoid litigation over the adequacy of disclosure. In contrast, "the ALI's proposal may lead to more nonmeritorious derivative suits challenging the adequacy of disclosure, not to eliminating such litigation." Elliot J. Weiss, Economic Analysis, Corporate Law, and the ALI Corporate Governance Project, 70 Cornell L Rev 1, 22 (1984) (discussing section 5.08 which governs conflict of interest transactions). These observations are relevant to section 5.05 since, as the same author observed, "The ALI Project proposes to use substantially the same approach with regard to all duty of loyalty transactions." Id at 19 n 87. 
some concession from the defendant; and

(3) the opportunity was not appropriate for the corporation because:

(A) such investment would be unreasonable due to the financial situation of the corporation; or

(B) such investment would not have been available to the corporation due to third parties' unwillingness to deal with the corporation; or

(C) the corporation had an implied or explicit policy against entering into investments with the characteristics of the challenged transaction.

\section{B. Argument for the Proposed Rule}

In practice, the proposed rule will require that participants disclose all outside business interests. ${ }^{84}$ Once the opportunity is disclosed, the corporation either will or will not be interested in taking it. In very clear cases, the corporation will know about the opportunity before the participant discloses her intention to invest. If the corporation has expressed some interest in the opportunity, then the participant must obtain rejection under part (1) of the proposed rule.

In most situations where the corporation wants the opportunity, it will express an interest and the participant will allow the corporation to take it. In those few cases where the participant still wishes to bid against the corporation, she may do so unless parts (2) (B) or (C) apply. Thus, participants must always offer opportunities of special value to the corporation, and the corporation can always contract for a rejection requirement.

The distinction between the proposed rule and the ALI rule surfaces in those cases where the corporation does not want the opportunity when the participant discloses it. In some of these cases, plantiffs will later attempt to claim these opportunities for the corporation. Under the ALI rule, the plantiffs will win whenever the participant has failed to satisfy rejection formalities. The proposed rule requires formal rejection in only a few cases. In other cases, the corporate participants will withhold rejection votes

\footnotetext{
84 As discussed previously, this will create some free rider problems (for example, when other participants make their own individual bids for opportunities disclosed to the corporation). See Section II.B. The free rider problem and the consequent decrease in incentives to seek opportunities are necessary but minor costs of a rule that adequately protects all participants and avoids impossible questions of fact that will arise without a disclosure requirement.
} 
in order to extract something from the participant wishing to hold outside investments. The ALI rule makes this a serious threat. The affirmative defense in the proposed rule allows the participant to invest without obtaining a rejection when other participants attempt to take unfair advantage of the rejection requirement.

\section{A standard based on the close corporation.}

Some commentators have argued that courts should apply a different level of fiduciary duty when assessing corporate opportunities in the context of closely held corporations. ${ }^{85}$ However, such an argument is misleading. Since most corporate opportunity cases involve closely held corporations, the corporate opportunity rule for close corporations is, in many ways, the corporate opportunity doctrine. A model law should not create a general rule that applies to very few cases, and an exception that applies to the "overwhelming majority" of cases. ${ }^{86}$ The proposed rule is based on the realities of the close corporation in order to deal properly with what is largely a close corporation problem.

In contrast to the approach taken in this comment, judicial and academic opinion has traditionally set a higher standard of fiduciary duty for participants in closely held corporations. ${ }^{87}$ This may be correct with regard to some manifestations of the duty of loyalty, but it does not follow that it is true for all. For example, a

ss Brudney and Clark, 94 Harv L Rev at 1000 (cited in note 1). Brudney and Clark cite the following factors as support for sometimes allowing close corporation participants to seize opportunities for themselves: the stockholders of a public corporation more closely resemble beneficiaries of a trust than do the joint venturers of a close corporation; the stockholders of a close corporation have a greater ability to select and monitor the directors; the investors in private ventures are small in number, tend to know each other, actively participate in management, and can give meaningful consent to corporate actions; the duties of public corporation executives usually require full-time application while officers of a close corporation may have outside interests and investments; the participants in a close corporation may agree or assume in the initial arrangements that directors are free to engage in other activities, and such consent may well be inferred; and finally, a public corporation will tend to be so large and flexible that all opportunities fall within its loosely defined line of business and ability to undertake. Id at 1001-1004.

so Id at 1061.

${ }^{87}$ See Donahue v Rodd Electrotype Co. of New England, Inc., 367 Mass 578, 328 NE2d 505, 515 (1975), limited by Wilkes v Springside Nursing Home, Inc., 370 Mass 842, 353 NE2d 657 (1967). The Donahue decision technically only established that stockholder/managers in close corporations owe each other a greater duty of loyalty than stockholders in public corporations. This result seems logical since one public stock owner has only a tenuous connection with another stockholder in the same venture. Nonetheless, Donahue has been used as authority for the general proposition that the close corporation generally carries with it a higher fiduciary duty. See, for example, Cain v Cain, 3 Mass App 467, 334 NE2d 650, 654-55 (1975). 
higher duty for close corporation actors may make sense with "squeeze outs" where the ease of communication and flexibility in a small corporation aid attempts by the majority to muscle out the minority. In the corporate opportunity context, on the other hand, flexibility and constant communication may mean that it is not necessary or useful to require a participant to obtain formal rejection of a business opportunity before taking it for herself.

Brudney and Clark have suggested that the difference in organizational form supports a more relaxed duty for close corporation participants in the corporate opportunity context ${ }^{88}$ and recent decisions have adopted this reasoning. ${ }^{89}$ Yet the perceived dichotomy between the publicly held and closely held corporate forms fails to support a different standard of loyalty. ${ }^{90}$

A more reasoned approach would base the level of fiduciary duty on the participants' role in the corporation. In Burg v Horn, for example, the Second Circuit recognized that the close corporation directorship usually carries a higher duty, but declined to impose that duty because the directors were not "full-time employees of [the corporation] with no prior real estate ventures of their own." "פ1 Under this approach, the public corporation's full time officer should have the highest duty; the public corporation's outside director should be held to the lowest standard; and the close corporation's jack-of-all-trades should fall somewhere in the middle, depending on the circumstances.

The ALI Project attempts to incorporate this flexibility but fails to recognize the primary distinguishing factor of the close corporation participant's role: multiplicity of function. Unlike their public corporation counterparts, most participants in closely held corporations simultaneously assume roles as officers, directors, and

ss Brudney and Clark, 94 Harv L Rev at 1006 (cited in note 1).

${ }^{89}$ One court recently stated: "We agree with commentators who argue that stricter rules related to the corporate opportunity doctrine are necessary when dealing with a public corporation. A more flexible approach, however, is dictated when dealing with a small corporation which is generally contractual in nature." Leavitt, 734 P2d at 1225 (citing Brudney and Clark). Klinicki, 695 P2d at 915-16, also noted the Brudney and Clark argument for a more lenient approach to close corporations.

${ }_{80}$ "The differences between publicly and closely held corporations, in other words, do not suggest unambiguously that the level of judicial scrutiny should vary or, if it does, in which direction." Easterbrook and Fischel, 38 Stan L Rev at 292 (cited in note 57).

${ }^{21} 380 \mathrm{~F} 2 \mathrm{~d}$ at 900 . See Note, 56 Georgetown L J at 389 (cited in note 22) (pointing out that if, as in Burg, the directors have other investments, a lower standard may be applied). Some courts have imposed a higher duty when the participants' corporation looks like a full time partnership. See, for example, Cain, 334 NE2d at 654-55, (court uses Donahue, a case involving a business with qualities of a partnership, as authority for imposing a higher duty on close corporations). 


\section{shareholders.92}

The result of the ALI rule is analogous to applying the rules of chess to a game of checkers. In chess there are many different participants with different functions. Thus, the rules of chess distinguish a queen from a rook and a rook from a pawn. Similarly, the rules for publicly held corporations can effectively distinguish between full time officers, outside directors, and shareholders. In contrast, checkers has only one playing piece. Like the close corporation participant, that one piece serves basically all of the functions of the game.

The proposed rule recognizes that close corporation participants, although perhaps not as fungible as checker pieces, cannot be separated neatly into categories like director, officer, and shareholder. Just as only one rule applies to the checker piece, one rule must cover all close corporation participants. A lenient rule allows each corporation to contract for the level of duty appropriate to each participant's role in the corporation.

\section{A presumption against formal rejection.}

Assuming that one rule will generally cover all corporate opportunity questions, a rule requiring formal rejection in all cases is not desirable. Instead, courts should presume that participants are free to engage in independent business activities in all cases except those that would directly damage the corporation, i.e., where the corporation especially needs the investment or has expended resources to obtain the opportunity. ${ }^{93}$

From the standpoint of administrative efficiency, there are at least two advantages of avoiding a formal rejection requirement. First, participants do not have to go through time consuming procedures every time they come across an opportunity that interests them. Second, the burden of contracting out of the less rigid rule, described below, falls on those few parties desiring absolute protection. Under a rule that generally allows participants to take opportunities, the costs of obtaining managers will be lowered and corporations that desire undivided attention may get it by contract.

In addition, a fiduciary duty that favors the individual partici-

92 Easterbrook and Fischel, 38 Stan L Rev at 273 (cited in note 57); Comment, 16 Land \& Water L Rev at 754 (cited in note 57).

${ }^{23}$ Courts have, at least in dicta, indicated that such a presumption is appropriate. See Guth, 5 A2d at 510; Lincoln Stores v Grant, 309 Mass 417, 34 NE2d 704, 707 (1941); Golden Rod Mining Co. v Bukvich, 108 Mont 569, 92 P2d 316, 320 (1939); Red Top Cab Co. $v$ Hanchett, 48 F2d 236, 238 (N D Cal 1931). 
pant will tend to keep the parties out of lawsuits since it corresponds more closely to parties' reasonable expectations as to when disclosure must be made and rejection obtained.94 The ALI rule requires that participants either offer to the corporation every business transaction that the corporation could find potentially advantageous or face liability. Inevitably, some participants will take the latter course-by choice, by mistake, or by coercion. In fact, the ALI intentionally facilitates lawsuits so that they will perform a monitoring function. ${ }^{95}$ Nonetheless, avoiding litigation is highly desirable since suits by corporations against participants are costly and generally benefit only the parties' attorneys. ${ }^{96}$

\section{Contracting out of the default rule.}

The rule proposed by this comment is a default rule and not a rule that is mandated in all cases. Parties may contract for a higher fiduciary duty if they desire by expressly limiting the ability of participants to engage in outside business activities. The fact that non-competition agreements in corporate management contracts are quite common indicates that similar provisions would not be difficult to negotiate. ${ }^{97}$ This rule allows the corporation and not the courts to determine the precise level of loyalty that governs its participants. ${ }^{98}$ Reliance on individual contracting is particularly

84 Many commentators have argued that fiduciary duty rules should approximate the bargain that participants would have reached if transactions costs were zero. Daniel R. Fischel, The Corporate Governance Movement, 35 Vand L Rev 1259, 1264 (1982). See also Frank H. Easterbrook and Daniel R. Fischel, Corporate Control Transactions, 91 Yale L J 698, 702, 703 (1982); Brudney \& Clark, 94 Harv L Rev at 999 (cited in note 1); Kenneth B. Davis, Jr., Judicial Review of Fiduciary Decisionmaking - Some Theoretical Perspectives, $80 \mathrm{Nw}$ U L Rev 1, 21 (1985); Richard A. Posner, Economic Analysis of Law 384 (Little Brown, 3d ed 1986).

${ }^{95}$ Statement of The Business Roundtable on the ALI's Proposed "Principles of Corporate Governance and Structure: Restatement and Recommendations" 36-38 (February 1983) ("the proposals themselves . . . are expressly designed to facilitate derivative litigation, not to minimize it. ... In essence, the model set forth in Tentative Draft No. 1 could properly be subtitled 'Governance by Litigation.' ").

Daniel R. Fischel, The Business Judgment Rule and the Trans Union Case, 40 Bus Law 1437, 1443-44 (1985); Fischel, 35 Vand L Rev at 1290-91 (cited in note 94) ("[L]egal rules making it more difficult and costly [for management] to dismiss derivative suits are extremely unlikely to increase shareholders' welfare.").

${ }^{97}$ See United Seal and Rubber Co., 285 SE2d at 723 (Hill concurring). Presiding Justice Hill agreed with the majority finding that there was no liability for former directors taking long established customers "because the employer failed to protect himself with covenants against competition, which it could have done."

${ }^{98}$ This approach should not be confused with the position taken by Brudney and Clark that a bright-line rule is appropriate for publicly held corporations, but a flexible rule should govern the taking of corporate opportunities by close corporation participants. "[I]t 
well suited to the flexibility of closely held corporations. ${ }^{99}$

Admittedly, it may be less practical for large corporations to contract with individual officers and directors for a higher duty of loyalty. Nonetheless, almost all corporate opportunity cases involve close corporations. In addition, some public corporations will not find it necessary to contract for a strict duty because the opportunities that the corporation pursues are too large for an individual officer or director to snatch away. Indeed, one major motivation for going public is to provide the capital that managers lack for big projects. Moreover, the one time gain of taking an opportunity is probably not worth the loss of the healthy salary that public corporation managers earn. Even if the corporation does not sue managers who usurp opportunities, it can always replace such managers.

If most public corporations do find it necessary to contract for a rule of formal rejection, the cost of negotiating should not be very high. Unlike the participants in family corporations, the full time officers of public corporations are likely to have extensive, carefully negotiated employment contracts. The public corporations probably have better information about what the corporate opportunity rule is and will know to negotiate an enhanced duty for corporate opportunity cases. In addition, since the full time officer of the public corporation is adequately compensated, she will probably not feel the pressure to engage in the multiple businesses common to small corporation participants. ${ }^{100}$

The proposed rule requires that the challenging participants satisfy certain conditions before the corporation may challenge the taking of an opportunity. The following section will explain those common law factors that courts should consider in deciding whether the participants challenging a transaction have overcome the presumption that such transactions will not constitute a breach of fiduciary duty.

is desirable to use a selective approach for close corporations and the categorical approach for public corporations." Brudney and Clark, 94 Harv L Rev at 1002 (cited in note 1). The proposed rule represents a clear rule for all corporations, but that bright line is drawn from the presumption that corporation participants may have outside business interests without incurring liability.

2 Brudney and Clark refer to the "essentially contractual relationships of [close corporations"] investors and managers," while calling for "sharper doctrinal responses [to] the claims of investors in public corporations ...." Id at 998 (emphasis added).

100 Id at 1003. 


\section{The Critical Common Law Factors}

As detailed in section I of this comment, courts typically examine several factors to determine the applicability of the corporate opportunity doctrine: a pre-existing relationship between the corporation and the opportunity, any special value of the opportunity for the corporation, the feasibility of corporate action, indications that the corporation waived any right to the opportunity, and additional considerations of fairness. The proposed rule incorporates the first four factors but leaves the fairness considerations to be addressed by other areas of corporation law.

First, the pre-existing relationship factor reflects the logic behind "interest or expectancy" without elevating it to the status of a dominant "test" that obscures other equally important factors. If some prior negotiation or contractual right ties the opportunity to the corporation, then the rule should require participants to disclose and obtain rejection. If the participant chooses not to offer the opportunity to the corporation, then she should have to prove some legitimate reason for that decision.

Second, if the opportunity has some "special value" to the corporation, then common sense dictates that the participant should offer it to the corporation. Although a corporation would probably allow participants to take advantage of most outside investments, corporations would presumably contract for the first crack at opportunities of special value to the corporation. Similarly, the presumption that corporations will tolerate outside investment may be overcome by a showing that the corporation had an explicit or implicit policy against such activity.

These presumptions only hold, however, in cases where a corporation lacks independent knowledge of the opportunity. If the corporation had independent knowledge of the opportunity and did not pursue the investment, then no duty to obtain rejection should arise. The reason that the knowledge must be independent is to prevent a defendant participant, who controls the information, from disclosing less than fully in order to defeat the corporation's cause of action. This rule ensures that the corporation will not attempt to sit on valuable opportunities and, at the same time, avoids the harshness of a formal rejection requirement. Knowledge and acquiescence (rather than formal rejection) more accurately reflect the realities of informal communication among small business participants. ${ }^{101}$

${ }^{101}$ See Leavitt, $734 \mathrm{P} 2 \mathrm{~d}$ at 1225 ("The small number of players in a private venture 
Conversely, if a corporation did pursue the opportunity, then the proposed rule requires that it should win unless the participant can demonstrate an affirmative defense. This reflects the intuition that parties would contract for a rule that requires fiduciaries to turn over opportunities that the corporation desires.

Even in those situations where the parties would have contracted for a duty to disclose and obtain rejection, the rule guards against opportunistic behavior by plaintiffs. It allows the defending participant to show both that she has a reasonable fear that the plaintiff participants will unfairly interfere with the investment, and that the corporation would not have undertaken the opportunity. ${ }^{102}$ In determining whether the corporation would have invested in the opportunity, the common law factors of corporate inability and waiver come into play.

Like the ALI, many jurisdictions have rejected the defenses of financial inability and refusal of third parties to deal with the corporation. The rejection presumably represents a reaction to the problem of participants withholding their best efforts in order to create the false appearance of corporate inability. But such a reaction is based on the questionable premise that participants will be willing to run their corporations into the ground in order to create inability. The threat of a direct suit for failure to use best efforts should adequately deter such conduct.

Finally, if a corporation chooses to pursue a limited variety of opportunities, then a rule requiring formal rejection of opportunities outside that set of investment types would invite opportunistic behavior by disinterested participants without providing any legitimate protection to the corporation. The common law factor of waiver addresses this concern. The corporate policy against some investments may be explicit or implicit. It may be based upon the risk level of some investments, or the limited expertise of the participants. A corporation may go through periods where participants understand that all further investments would be unwise. Nonetheless, under the ALI proposal a participant still has an obligation

result [sic] in better communication between the members. Additionally, agreements are entered into which are tailored to particular situations and objectives.").

${ }^{102}$ Examples of reasonable fear of unfair interference are fears that other participants will bid for the opportunity as individuals, that other participants will withhold their rejection votes in order to extract payment or bargaining advantages from the participant, or that other participants will withhold their rejection in order to "squeeze out" the participant by forcing her to sell her shares at a deflated price. Note that these fears constitute a defense for nondisclosure only when the participant can show that it was more likely than not that the corporation would have refused the opportunity. 
to obtain a formal rejection before proceeding. This cumbersome gesture may be pointless and wasteful as well as an invitation to hold out during a rejection vote.

\section{The "Fairness" Factors}

The factors discussed above should supply all of the information necessary to decide whether a participant's appropriation of a corporate opportunity constituted a breach of duty. Nonetheless, many courts have considered other factors under a heading of "fairness". ${ }^{103}$ For the reasons given below, these factors are more properly dealt with under either the inquiry laid out above or under a different branch of the fiduciary duty of loyalty; they may also be irrelevant to the question of whether a participant has breached her fiduciary duty of loyalty.

First, courts have consistently recognized the use of corporate assets as a factor bearing heavily on the unfairness of a participant's appropriation of an opportunity. ${ }^{104}$ When a corporate participant uses corporate property, funds, confidential records, or employees to discover, develop, or obtain an opportunity for herself, the corporation deserves to hold the beneficial opportunity in constructive trust. ${ }^{105}$ Most judges have an instinctively negative reaction to the use of corporate property to secure a business transaction for an individual's profit. ${ }^{106}$ The basis of this negative reaction, however, is not that the individual should not have taken the opportunity. Rather, the fundamental unfairness in such a situation is that the corporate property was used for purposes other than corporate profit. Thus, the corporation should sue the guilty participant for misappropriation of the assets. ${ }^{107}$

${ }^{103}$ See, for example, Miller v Miller, 222 NW 2d at 81-82; Comment, $2 \mathrm{~J}$ Corp L 405 (cited in note 79).

${ }^{104}$ See Guth, 5 A2d at 515, where the Pepsi product was developed using the soda fountain's resources. See also Durfee, $80 \mathrm{NE2d}$ at 529. The Durfee decision, often referred to as the seminal case for a pure fairness test of the corporate opportunity doctrine, notes that the defendant director employed the resources of the corporation. In Solimine $v$ Hollander, the court, though announcing a very relaxed standard, prohibited the use of corporate funds, resources, or facilities to acquire an opportunity for the director. $16 \mathrm{~A} 2 \mathrm{~d}$ at 220 . See also, Note, Corporate Opportunity, 74 Harv L Rev 765, 777-78 (1961).

105 See Note, 56 Georgetown L J at 384 (cited in note 22).

${ }^{108}$ But see In Re Central Pacific Boiler \& Piping, Ltd., 81 Bankr at 45-46 (court allowed defendant to borrow money on corporation's line of credit in order to obtain the challenged opportunity where corporation knew of the practice, corporation was never prevented from drawing further on that line of credit, and all of defendant's personal assets were pledged toward that line of credit).

${ }_{107}$ See Williams $v$ Queen Fisheries, Inc., 2 Wash App 691, 469 P2d 583, 586 (1970), for a case imposing a strict rule against use of corporate equipment, employees, or money to 
Nonetheless, use of corporate assets may be useful in proving misappropriation of a corporate opportunity, for it may indicate that the corporation had a close connection to the opportunity. In that way the exploitation factor will go to establishing a pre-existing relationship between the company and the opportunity. Similarly, a participant's use of corporate funds to undertake an opportunity undermines any future argument that the corporation lacked the financial ability to take the opportunity on its own.

Second, courts often examine whether the opportunity was presented to the participant in an official as opposed to an individual capacity. Nonetheless, this consideration does not represent a distinct question of fairness, for when an offeror presents an opportunity to a participant with the understanding that he is presenting it to the corporation, there is a pre-existing relationship between the company and the opportunity.

Third, some courts note that, in developing their individual opportunities, the challenged directors neglected their duties to the complaining corporation. Though this may amount to a breach of fiduciary duty, it has no connection to the doctrine of corporate opportunity. If the director neglects her duties, the cause of her distraction is irrelevant. Conversely, if the director fulfills all her duties, the corporation cannot complain of her outside projects.

Fourth, courts often express disapproval when a defendant created a new corporation in which to deposit the challenged opportunity. ${ }^{108}$ The choice to use a corporate form to take advantage of an opportunity, however, is irrelevant to whether the taking of that opportunity constitutes a breach of some fiduciary duty. Obviously, the corporate form is desirable for many investments. If the individual can take the opportunity, the method of appropriation should not concern the courts.

Fifth, when a participant invests in an area closely related to the business of the complaining corporation, courts sometimes confuse the issue of usurpation of corporate opportunity with the issue of detrimental competition with the corporation. ${ }^{100}$ That a new op-

acquire opportunities in a jurisdiction with virtually no cases under the doctrine of "corporate opportunity" as such. The ALI Project deals with the misappropriation of corporate assets under $\S 5.04$ (cited in note 2). See also Restatement (Second) of Agency $\S 404$ (1958); Restatement (Second) of Trusts $\$ \$ 170,206$, comment j (1959).

${ }^{10 s}$ See, for example, Klinicki, 695 P2d at 920; Production Finishing Corp., 405 NW2d at $175 ;$ Guth, 5 A2d at 507.

109 See Lincoln Stores, 34 NE2d 708 (court did not clearly distinguish between the corporate opportunity question and the competition question in declining to impose a constructive trust on opportunity taken by participant). 
portunity may throw the participant into competition with the corporation does not increase the justification for finding the taking of that opportunity a breach of fiduciary duty. Instead, that competition may make the continued involvement in that opportunity a breach of fiduciary duty under the doctrine of detrimental competition. $^{110}$ To avoid doctrinal confusion, courts should deal with competition as an independent and distinct breach of duty. ${ }^{111}$

Sixth, a related practice, often considered by courts as unfair, is the resale of an opportunity to the corporation at a profit. Again, this activity seems to present two distinct duty of loyalty questions. Was the initial appropriation of the opportunity by the individual a breach of duty? And, separately, was the sale of an opportunity to the corporation a breach of duty? The corporation's eventual purchase of the opportunity is perhaps strong evidence that the opportunity was closely related to the corporation's interests, but the self dealing question itself should be considered as a separate cause of action.

Finally, courts express particular sensitivity to the vulnerability of close corporation participants to unfair pressures by the majority. ${ }^{112}$ Apparently, the reasoning is that diversion of opportunities as part of an overall scheme to squeeze out minority shareholders is somehow worse than diversions for other reasons. ${ }^{113}$ Nonetheless, the issue still remains simply whether the participant has a duty to offer the opportunity to the corporation. Regardless of whether a participant has good or bad motives, if there is no duty to offer the opportunity to the corporation then there is no liability under a corporate opportunity doctrine. Courts can directly mitigate the risks of squeeze outs in small corporations by acknowledging a separate fiduciary duty to avoid such tactics. ${ }^{114}$

110 The ALI project deals with the competition problems under a separate section from corporate opportunity. ALI Project, $\$ 5.06$ at 125 (cited in note 2) ("Competition with the Corporation").

11 This factor is often dealt with by non-competition provisions in the participant's contract. See, for example, Production Finishing Corp., 405 NW2d at 176.

112 See Donahue, 328 NE2d at 513.

113 It is possible to facilitate a squeeze out by taking all of the corporation's opportunities. See, for example, Harper, 1987 WL 18414. Nonetheless, the typical corporate opportunity case will not involve schemes to eliminate minority shareholders by diverting all of the corporation's business.

114 Orchard, 590 F Supp at 1557 ("It follows that any attempt to 'squeeze out' the minority shareholders must be viewed as a breach of this fiduciary duty."). 


\section{Conclusion}

The corporate opportunity doctrine is unusual in that, for the most part, it affects closely held corporations. Rules governing these corporations must take into account the relaxed formality and the fusion of shareholder, officer, and director roles in close corporation governance.

Because the common law doctrine of corporate opportunity relies on disorganized lists of factors, not all of which are relevant, it fails to provide guidance to corporate participants. The ALI attempt to restructure this doctrine cures some of these ills but relies too heavily upon nice distinctions that cannot be made in the close corporation context. The resulting rule is clearer than the common law, but it places a heavy burden upon corporate participants, increases the cost of attracting investors, and invites opportunistic behavior. A more reasoned approach would give participant's greater freedom to hold outside business interests. The proposed rule preserves the benefits of individual incentives to seek out and obtain lucrative investments while allowing corporations to protect themselves by contracting for higher standards when desired. 
